\title{
Underground transfer of carbonised organic residues to lithics during preliminary fire experiments: implications for archaeology
}

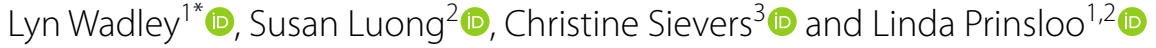

\begin{abstract}
Using fire experiments, we investigate claims that black organic residues on lithics found in Stone Age sites are markers for heat treatment of rocks in the embers of aboveground wood fires. We buried sedges overlain with lithics and bone to replicate plant bedding sometimes found in archaeological sites. Small fires were lit over the material buried under a mixture of coarse- and medium-grained sand. Black carbonised residues formed on several lithics that were in direct contact with buried sedges that burned below the fire. FTIR, Raman and preliminary GC-MS measurements were made on dried and burnt sedge, burnt bone, and on a prominent black residue that formed on one quartz piece that had been in contact with buried fresh sedge when it was heated. Importantly, we were able to confirm the spontaneous and accidental transfer of organic compounds to lithics buried and heated underground in the presence of plant material. This means that carbonised organic residues are not useful markers for determining whether heat treatment of rocks took place above or below ground. Our preliminary experiments imply that further work should be done to investigate the causes of the residues formed on lithics underground.
\end{abstract}

Keywords: Incidental organic residues, Lithics, Wood fires, FTIR, Raman, GC-MS

\section{Introduction}

Fires have been purposefully produced by people for tens of thousands of years for cooking, light, warmth, protection from predators, and tasks like the heat treatment of rocks $[1,2]$. Heat treatment changes the internal structure and improves the flaking properties of rocks and minerals that were not geologically heated above temperatures reached by camp fires. There are debates about the feasibility of heat treatment directly in embers as opposed to burial of rocks a few centimeters in sediment substrate below a fire [3]. The issues are not trivial because when rocks are deliberately buried the unseen heating task implies analogical reasoning, an attribute of complex cognition [4]. Experiments and replications create comparative collections of attributes displayed on heated rocks and minerals. These are invaluable for

\footnotetext{
*Correspondence: lyn.wadley@wits.ac.za

${ }^{1}$ Evolutionary Studies Institute, University of the Witwatersrand, PO Wits

2050, Johannesburg, South Africa

Full list of author information is available at the end of the article
}

identifying heating processes on rocks and minerals from archaeological sites. Potlids (small concave pockmarks), for example, only form in the presence of oxygen and they demonstrate above ground heating, while crazing is an attribute of overheating [5]. Schmidt and colleagues [6] interpreted a black organic residue (which they also called 'tempering residue') as an accidental deposit that formed on silcrete heat treated in the embers of an open fire using green wood. This evidence informed their subsequent conclusions that open-fire heat treatment of silcrete took place at the South African Middle Stone Age sites of Diepkloof Rock Shelter [3, 6] and Klipdrift [7]. In contrast, Brown et al. [2] deduced from their experiments that silcrete must be heat treated underground to avoid catastrophic cracking and they suggest that this method might have been used at Pinnacle Point more than 160,000 years ago.

To avoid misinterpreting fire technology in the past, deliberate burning for purposes like heat treatment must be distinguished from unintentional, post-depositional 
burning. Black carbonaceous layers in the stratigraphy of archaeological sites can sometimes represent organic material charred fortuitously within the soil substrate [8]. Items heated and burned accidentally and residues formed on objects post-depositionally, or as part of natural site formation processes [9], can cause confusion if they are not correctly identified. The black organic residue that Schmidt et al. [6] produced while heating silcrete is another key example demonstrating that not all residues on lithics need be use-related. In their case the residues formed, not post-depositionally, but as unintentional byproducts of deliberate heat treatment. Here we conduct a pilot study to investigate the possibility that black organic residues of the type produced in above ground fires by Schmidt et al. [6] can also be fortuitously produced underground when lithics and organic materials are buried together in sediment and overlain by a camp fire.

At Sibudu, a rock shelter in KwaZulu-Natal, South Africa, bedding was made with sedges between 77,000 and 38,000 years ago [10-12] and the plant layers were probably used not only for sleeping, but also as clean places for working because lithic artefacts and bone fragments occur among the sedges. Sibudu's bedding was often burned, probably deliberately for site maintenance, but perhaps the burning was sometimes unplanned. These archaeological findings prompted us to use sedges as the primary plant component of our replicated, buried bedding, but we added a few twigs and leaves of Tarchonanthus camphoratus L., an aromatic, camphor-like plant identified at Sibudu [13]. Lithics and bone were laid on the sedges before burial because this type of association is detected in Sibudu. In the event that residues were found to form underground, three analytical techniques that have proved effective in previous studies were selected for chemical analyses: Raman spectroscopy ([14, 15] and references therein), Fourier transform infrared (FTIR) spectroscopy ([16-18] and references therein) and gas chromatography-mass spectrometry (GC-MS) ([19-24] and references therein).

\section{Methods}

\section{The burning experiments}

This report describes two experimental fires. Ambient temperature and humidity were measured with a Brannan wet and dry bulb whirling hygrometer. The loose sediment on which the experiments were conducted derived from sand, a weathered product of Waterberg sandstone. It was assessed in three ways. Sediment moisture content was measured with a Theta Probe soil moisture sensor (Type ML2x). The colour of the sediment was recorded with the Munsell chart. The particle size of sediment samples was determined by sieving the samples through a stack of geological sieves and applying the Wentworth [25] grain size classification.

Plant material comprised small bundles of sedge, Cyperus textilis Thunb., topped with tiny twigs and leaves of Tarchonanthus camphoratus. Moisture content of sedges might potentially affect their combustibility, so both dry, brown and fresh, green Cyperus culms were cut from the plants. The culms were stored for 3 weeks before the experiments so the 'green' sedges were not really fresh when they were burned. The moisture contents of the two sedge samples were measured using a MC-7825S moisture meter.

Items used in the experiment were collected from LW's property. The bone used was from animals that had died of natural causes. The vertebra of an adult male giraffe that had died a year previously was broken with a mallet. Fresh bone from the neck of an adult kudu bull was similarly broken.

Experiment 1: A shallow $80 \mathrm{~cm}$ long trench was excavated into sediment within a brick enclosure (to prevent run-away fire). Dry sedge (1 kg) was laid the full length of the trench. Dry and fresh bone splinters were spread across the top of the sedges, together with two quartz chunks, one shale and one chalcedony chunk (Additional file 1). Twigs and leaves of Tarchonanthus camphoratus were placed over the sedge layer strewn with lithics and bone. Thermocouples were placed at the base and top of the sedge, under the centre of the sedge feature. Another thermocouple was placed on the surface of the sedges at the edge of the fire. A further two thermocouples were placed on the sediment surface in the centre of the fire, and one thermocouple was placed on the surface at the perimeter of the fire. A thermocouple was placed on top of a quartz piece lying on the sedges. Another thermocouple was placed on the sedge surface on a culm base.

Experiment 2: A shallow $80 \mathrm{~cm}$ long trench was excavated as before. Green sedge $(1 \mathrm{~kg})$ was laid the full length of the trench. Dry and fresh bone splinters were spread across the top of the sedges, together with three quartz chunks, and one each of shale, quartzite and hornfels (Additional file 1; Figs. 1 and 4). Twigs and leaves of Tarchonanthus camphoratus were placed over the sedge and lithic and bone items. Thermocouples (dual K-type, each $70 \mathrm{~cm}$ in length) were placed at the base and top of the sedge, at the centre of the feature. Another thermocouple was placed on the surface of the sedges at the edge of the fire. A further two thermocouples were placed on the sediment surface in the centre of the fire and one thermocouple was placed on the surface at the perimeter of the fire. Thermocouples were placed at the top and base of a piece of quartz laid on top of the sedge, but under the Tarchonanthus camphoratus leaves. The last thermocouple was placed on top of a hornfels piece lying 

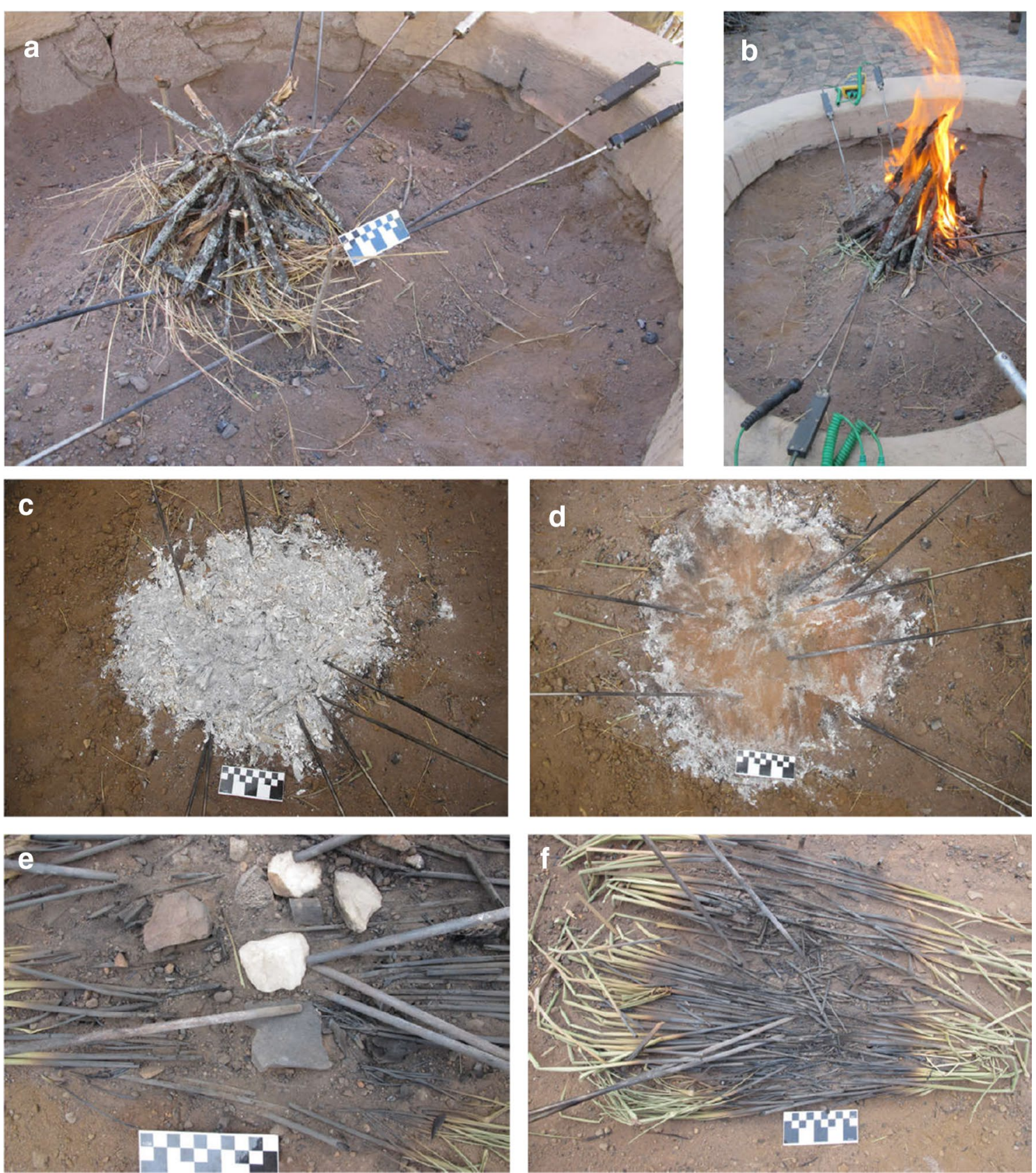

Fig. 1 Experiment 2. a Wood set for fire, $\mathbf{b}$ fire with thermocouples, $\mathbf{c}$ top white ash after fire was extinguished, $\mathbf{d}$ pink ash under white ash, e lithics and bone excavated, $\mathbf{f}$ lithics and bone removed to show the extent of sedge burning under the fire

on the sedge, but under the Tarchonanthus camphoratus. Temperatures were measured with Extech temperature data loggers (HD200).

In both experiments the replicated bedding was covered with $5 \mathrm{~cm}$ of sand above which small fires were lit with Acacia karroo Hayne wood that is indigenous to South Africa. Acacia was used as firewood at Sibudu
[26]. Experiment 1 was conducted with 1127 g A. karroo bark, $1536 \mathrm{~g}$ twigs and small branches, and $2240 \mathrm{~g}$ logs (eight pieces). Experiment 2 was conducted with $1049 \mathrm{~g}$ bark, $1760 \mathrm{~g}$ twigs and small branches, and $2260 \mathrm{~g} \operatorname{logs}$ (eight pieces). The moisture content of the $A$. karroo wood was measured using a MC-7825S moisture meter. After lighting the fires, the temperature readings were taken every $15 \mathrm{~min}$. 


\section{Raman spectroscopy}

Raman spectroscopy was chosen to analyse all charred materials, as it is one of the few techniques that can detect amorphous carbon, the main component of char. Raman spectra were recorded on burnt bone and quartz (both from Experiment 2). WITec ${ }^{\circledR}$ alpha 300R confocal Raman microscope (WITec ${ }^{\circledR}$ Instrument Corp., Germany) equipped with a UHTS300 spectrometer and a visible DV401 detector for use with $532 \mathrm{~nm}$ excitation. The excitation source was a $532 \mathrm{~nm}$ diode laser with 38 $\mathrm{mW}$ maximum power output. Zeiss ${ }^{\circledR}$ microscope objectives ( $20 \times$ and $50 \times$ magnifications) were used, achieving sub-micron spatial resolution. The samples were placed on a piezo-driven, feedback-controlled scanning stage.

\section{Fourier transform infrared (FTIR) spectroscopy}

FTIR spectroscopy complements Raman spectroscopy and infrared spectra were recorded of dried (but still green), partially burnt (brown) and charred (black) sedge samples in the mid-infrared region. The blackened bone sample and scrapings from the quartz (Experiment 2) were also analysed. A diamond ATR cell, which fits in the macro sample compartment of a Vertex 70v (Bruker Optics) spectrometer, was used to record spectra with 32 acquisitions at $4 \mathrm{~cm}^{-1}$ resolution over a spectral range of $4000-400 \mathrm{~cm}^{-1}$. The sample compartment was evacuated during acquisitions and the contact area between the sample and the diamond ATR crystal is $2 \mathrm{~mm}$ diameter.
The dried and partially burnt sedge culms were placed directly on the ATR cell, while the bone, charred sedge and scrapings of the quartz were in powdered form.

\section{Gas chromatography-mass spectrometry (GC-MS)}

Measurements were taken of dried sedge, charred sedge, the quartz stone, residue on the quartz, and burnt/heated bone. All detailed GC-MS methods and results are presented in Additional file 2.

\section{Results}

\section{Experimental fires}

The moisture content of wood and sedge and the mass of the materials used in each experiment are recorded in Table 1. The sediment used for the experiments comprised a mixture of coarse- and medium-grained sand, measured on the Wentworth [25] particle size class scale of $1.0-0.5 \mathrm{~mm}$ for coarse sand and $0.5-0.25 \mathrm{~mm}$ for medium sand (Table 1 ). The relatively high ambient temperature and low humidity (Table 2) probably contributed to the fairly quick ramping of fire temperatures both above and below ground (Figs. 2 and 3). Within $1 \mathrm{~h}$, the surface fire temperature in Experiment 1 was $340{ }^{\circ} \mathrm{C}$ while the temperature at the top of the sedges, $5 \mathrm{~cm}$ below ground, was $166^{\circ} \mathrm{C}$ (Fig. 2; Table 2). Experiment 2 temperatures were slightly hotter; $1 \mathrm{~h}$ from lighting the fire a temperature of $481{ }^{\circ} \mathrm{C}$ was achieved

Table 1 Experiments 1 and 2: moisture content and mass measurements of wood and sedge, and moisture content, particle size (Wentworth scale) and Munsell colour readings of substrate sediment before the fires were lit

\begin{tabular}{|c|c|c|c|c|c|c|c|c|}
\hline \multirow[t]{2}{*}{ Item } & \multicolumn{4}{|l|}{ Experiment 1} & \multicolumn{4}{|l|}{ Experiment 2} \\
\hline & Moisture (\%) & Mass (g) & Colour (Munsell) & $\begin{array}{l}\text { Particle } \\
\text { size }(\mathrm{mm})\end{array}$ & Moisture (\%) & Mass (g) & Colour (Munsell) & $\begin{array}{l}\text { Particle } \\
\text { size }(\mathrm{mm})\end{array}$ \\
\hline Substrate sediment & 0.1 & - & 7.5YR 5/3 brown & $\begin{array}{l}\text { Coarse/ } \\
\text { medium } \\
\text { sand, } \\
1.0-0.25\end{array}$ & 0.1 & - & 7.5YR 5/3 brown & $\begin{array}{l}\text { Coarse/ } \\
\text { medium } \\
\text { sand, } \\
1.0-0.25\end{array}$ \\
\hline Wood & $11.2-13.7$ & 4873 & - & - & $11.2-13.7$ & 5069 & - & - \\
\hline Sedge & $6.2-11.4$ & 1000 & - & - & 14.3 & 1007 & - & - \\
\hline
\end{tabular}

Table 2 Summary of temperatures associated with each experiment

\begin{tabular}{lcc}
\hline & Experiment 1 & Experiment 2 \\
\hline Ambient temperature, ${ }^{\circ} \mathrm{C}$, at start & 21.0 & 22.0 \\
Humidity (\%) at start & 18.0 & 21.0 \\
Maximum temperature, ${ }^{\circ} \mathrm{C}$, reached in fire centre & 485.4 & 506.6 \\
Maximum temperature, ${ }^{\circ} \mathrm{C}$, reached at perimeter & 370.0 & 358.0 \\
Maximum temperature, ${ }^{\circ} \mathrm{C}$, reached at base of buried sedges & 256.1 & 215.1 \\
Maximum temperature, ${ }^{\circ} \mathrm{C}$, reached at top of buried sedges & 438.3 & 426.4
\end{tabular}

Ambient temperature and humidity are included 


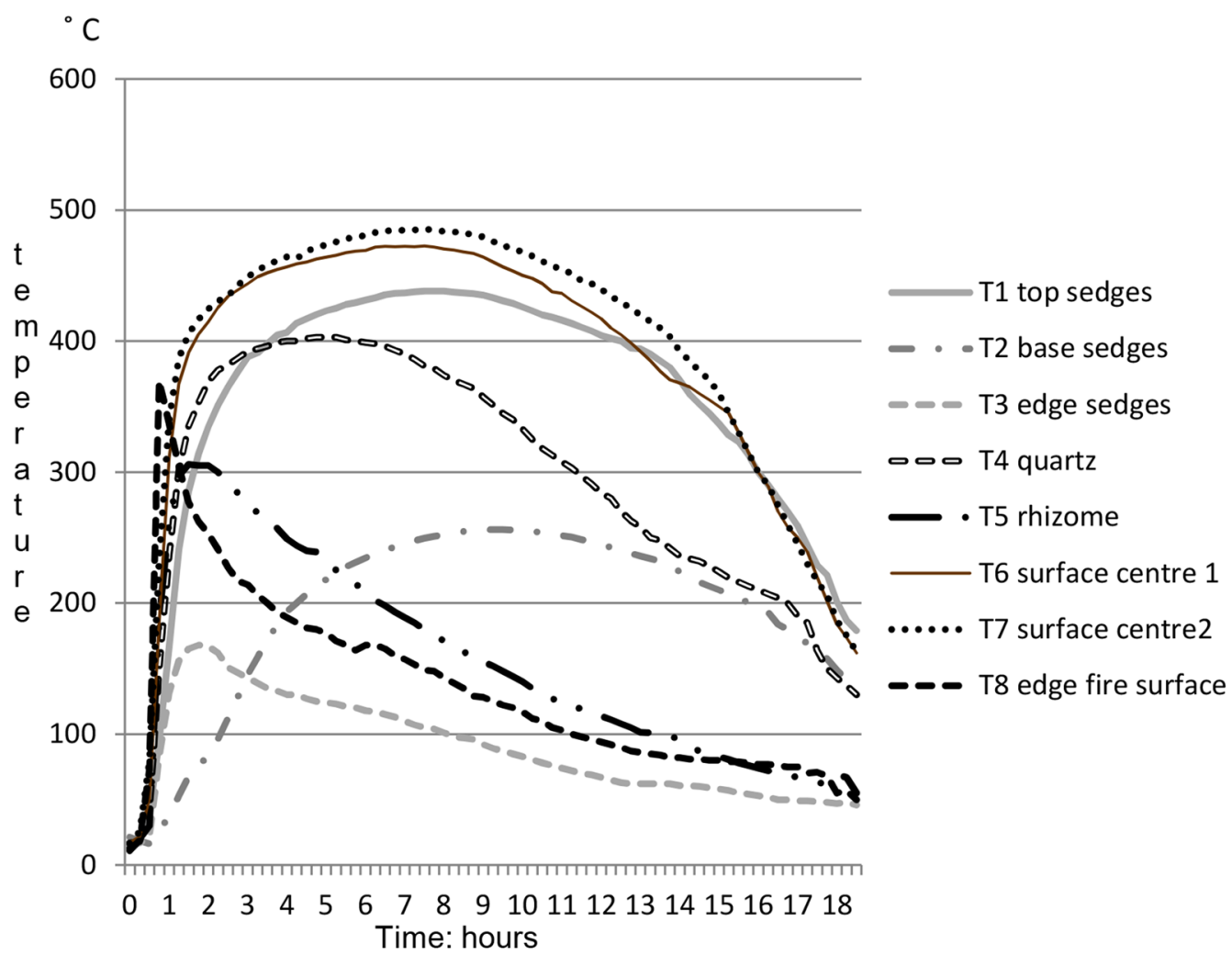

Fig. 2 Fire Experiment 1 temperatures through time, above and below ground surface. The $Y$-axis is temperature in degrees $C$; the $X$-axis is time in $1 \mathrm{~h}$ intervals. $\mathrm{T}=0$ is defined as the time when the fires were started

in its centre at the same time that the top of the sedges $5 \mathrm{~cm}$ underground reached a temperature of $339{ }^{\circ} \mathrm{C}$ (Fig. 3).

After combustion and cooling, the hearths comprised white surface ash underlain with rubefied ash and sediment (Fig. 1c, d). When the sediment was excavated the lithics and large pieces of bone were exposed lying on the burnt sedges (Fig. 1e). The Tarchonanthus leaves, sedge culms and bone fragments burned precisely below the area where the fires were placed, but remained unburnt outside of the fire circle. Bone placed on sedge under the fire was blackened, but where bone splinters straddled the fire and the area outside the fire, their colour was variegated, part blackened (under the fire) and part light in colour (outside the fire perimeter). Initially, when the lithics were exposed no change was noticeable on their uppermost surfaces (Fig. 1e). However, when the quartz chunks and one hornfels flake were lifted, their undersides resting on the burnt sedges were flecked with a persistent black residue. On one quartz piece in Experiment 2, the thick black residue measured $25 \mathrm{~mm}$ in length (Fig. 4b). The residues and plant material were thereafter subjected to chemical tests.

\section{FTIR and Raman}

Plant material is composed of an intricate matrix of cellulose and hemicellulose polysaccharides, lignin and extractives (non-structural components) [27]. Cellulose is a linear polymer of $\beta$-D-glucopyranose units; hemicellulose mostly consists of polysaccharides of low molecular weight and both cellulose and hemicellulose contain hydroxyl, ether and carbonyl functional groups. Lignin is a complex highly aromatic substance and acts as a cementing matrix between and within both cellulose and hemicellulose units [28]. Heating plant material causes dehydration, the loss of volatiles and in the presence of oxygen complete combustion of all remaining hydrocarbons to carbon dioxide and water with only wood ash (with calcium carbonate as main component) remaining. In the absence of oxygen, pyrolysis of plant material results in depletion of aliphatic species (non-aromatic compounds) and development of amorphous aromatic structures (bio-char), which can contain traces of noncarbonised material depending on pyrolysis temperature. The sedges, covered by sand and placed underneath the fire, undergo both combustion and pyrolysis, subject to the availability of oxygen (some of which can enter coarse-grained sediment). Volatiles released during the 


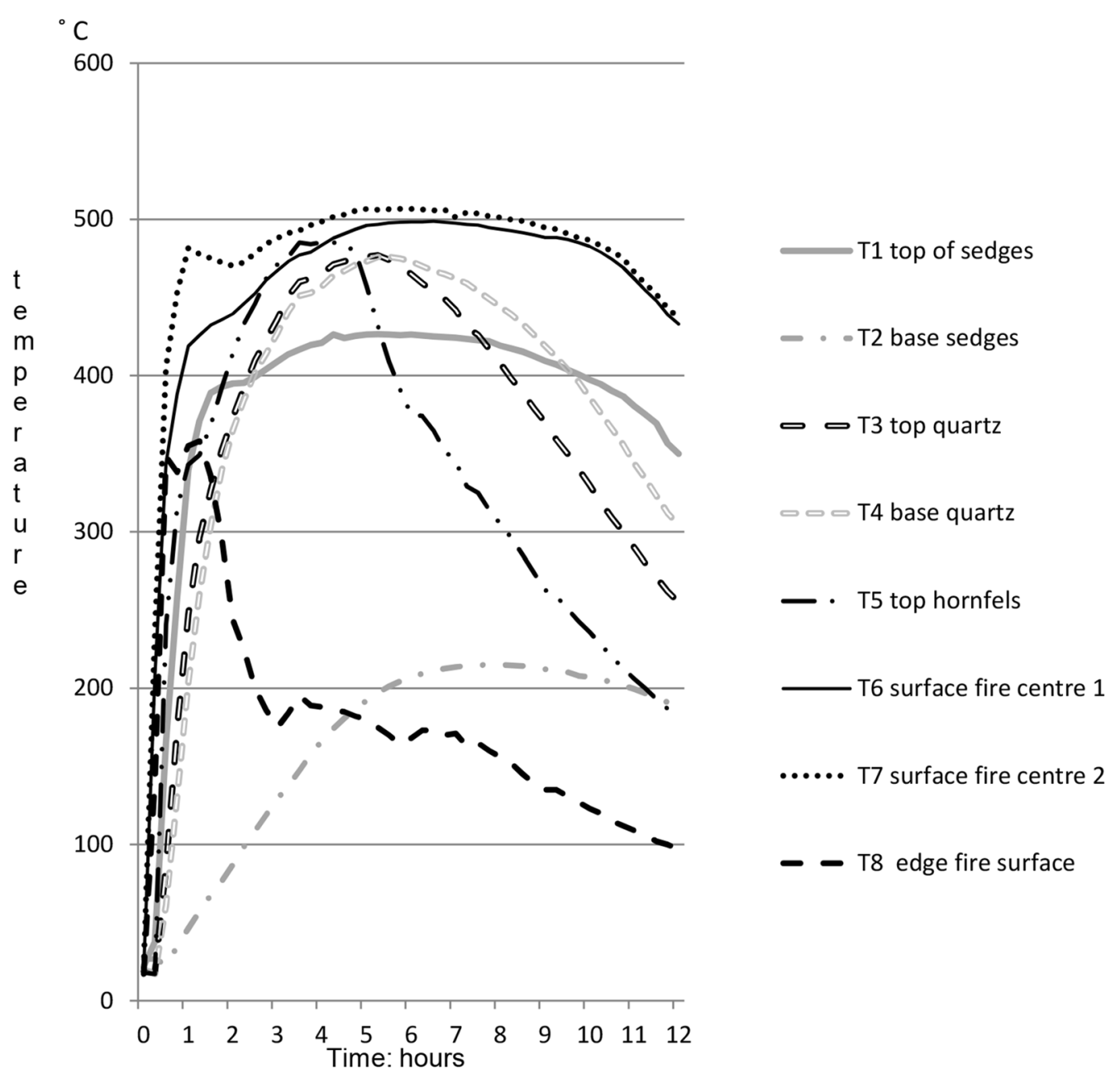

Fig. 3 Fire Experiment 2 temperatures through time, above and below ground surface. The $Y$-axis is temperature in degrees $C$; the $X$-axis is time in $1 \mathrm{~h}$ intervals. $T=0$ is defined as the time when the fires were started

early stages of both combustion and pyrolysis may disperse underneath the sediment and condense on other objects during cooling (referred to as dry distillation in some of the literature) if there is no direct escape route to open air.

Figure 5 compares FTIR spectra recorded from the dried, burnt and charred sedges to a spectrum recorded on the large black residue observed on the quartz piece placed on top of fresh sedges (Experiment 2). Bands typical of plant material such as the $\mathrm{C}=\mathrm{O}$ stretch $\left(1740 \mathrm{~cm}^{-1}\right)$ of esters, ketone etc., $\mathrm{C}-\mathrm{O}-\mathrm{C}$ and $\mathrm{C}-\mathrm{O}$ vibrations of cellulose and hemicellulose (1153 and $\left.1030 \mathrm{~cm}^{-1}\right)$ and aromatic skeletal vibrations of lignin $\left(1593 \mathrm{~cm}^{-1}\right.$ and $1505 \mathrm{~cm}^{-1}$ ) appear in the spectrum of the dried sedge. In the spectra of the partially burnt sedges, peaks from $\mathrm{O}-\mathrm{H}, \mathrm{C}-\mathrm{H}$ and $\mathrm{C}=\mathrm{O}$ stretching have partially disappeared, while a strong broad band due to $\mathrm{C}=\mathrm{C}$ aromatic stretch vibrations (1506-1590 $\mathrm{cm}^{-1}$ ) appeared.
The spectrum of the charred sedge is similar, but $\mathrm{C}-\mathrm{H}$ vibrational bands completely disappeared. In the spectra of the partially burnt and charred sedges the characteristic band of $\mathrm{CaCO}_{3}$ at $874 \mathrm{~cm}^{-1}$ indicates the presence of wood ash that suggests that partial combustion took place. In the spectrum of the black deposit on the quartz a broad band around $1580 \mathrm{~cm}^{-1}$ indicates the presence of aromatic carbon structures, which might be due to pyrolysis of material originating from the sedges. Bands originating from the quartz are also present in the spectrum. The Raman spectrum recorded on the same black residue (Fig. 5, right), consists of two broad peaks typical of amorphous carbon at 1360 and $1580 \mathrm{~cm}^{-1}$, known as the $\mathrm{D}\left(\mathrm{sp}^{3}\right)$ and $\mathrm{G}\left(\mathrm{sp}^{2}\right)$ bands respectively. In the spectrum recorded on the quartz adjacent to the black residue these two peaks are also visible.

Figure 6a compares the FTIR spectrum of a piece of the black bone sample to a spectrum of fresh pork bone. 

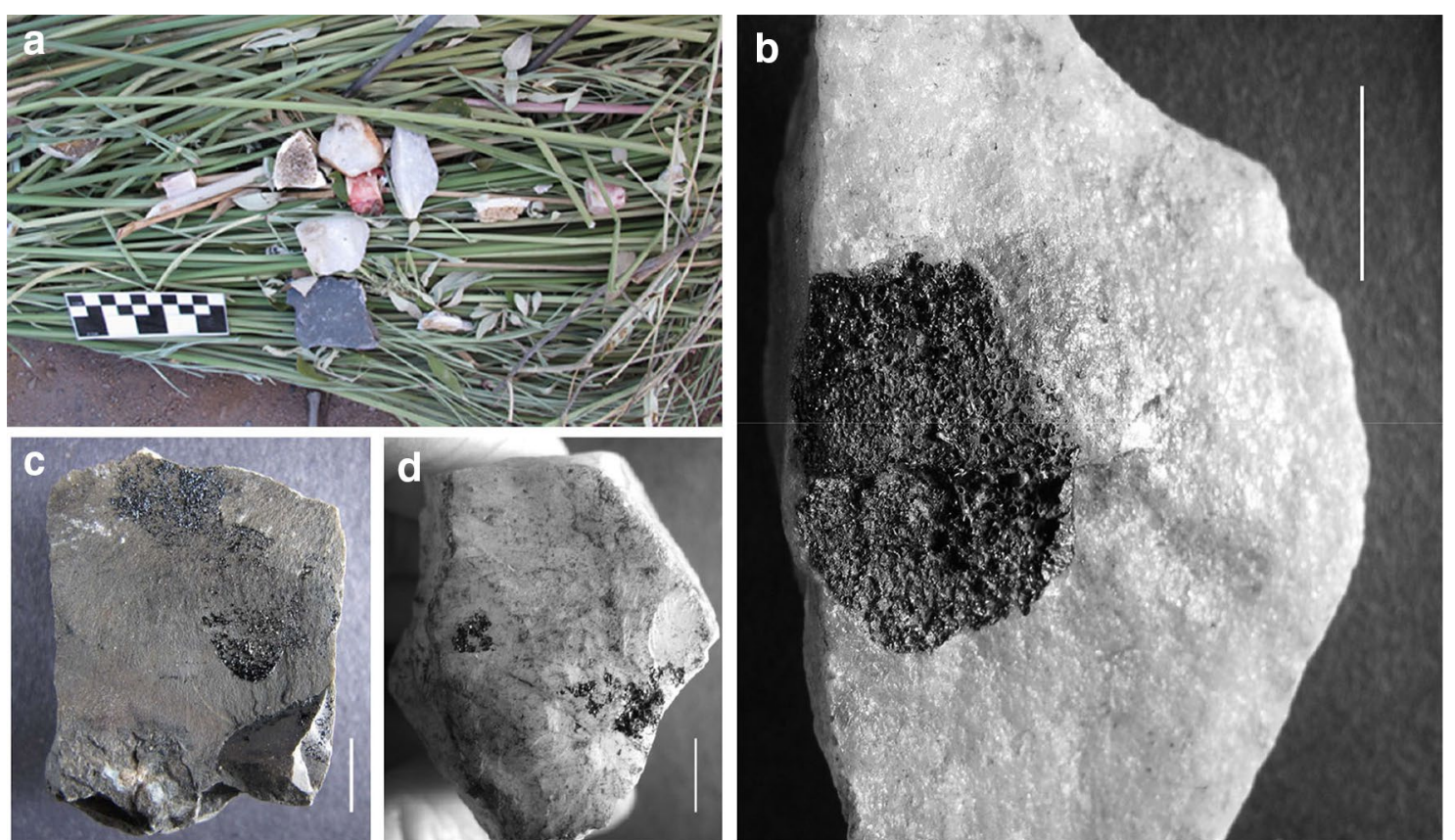

Fig. 4 Experiment 2 examples of lithics and bone heated on fresh sedges. a Lithics and bone on sedge before burial and burning. $\mathbf{b}$ Black residue on quartz (piece at the top right of the cluster of items in $\mathbf{a}, \mathbf{c}$ ). Black residue on hornfels piece (base of $\mathbf{a}$, near scale bar), $\mathbf{d}$ black residue on quartz (this piece is left of $\mathbf{b}$ on the sedges). The white scale bars represent $10 \mathrm{~mm}$
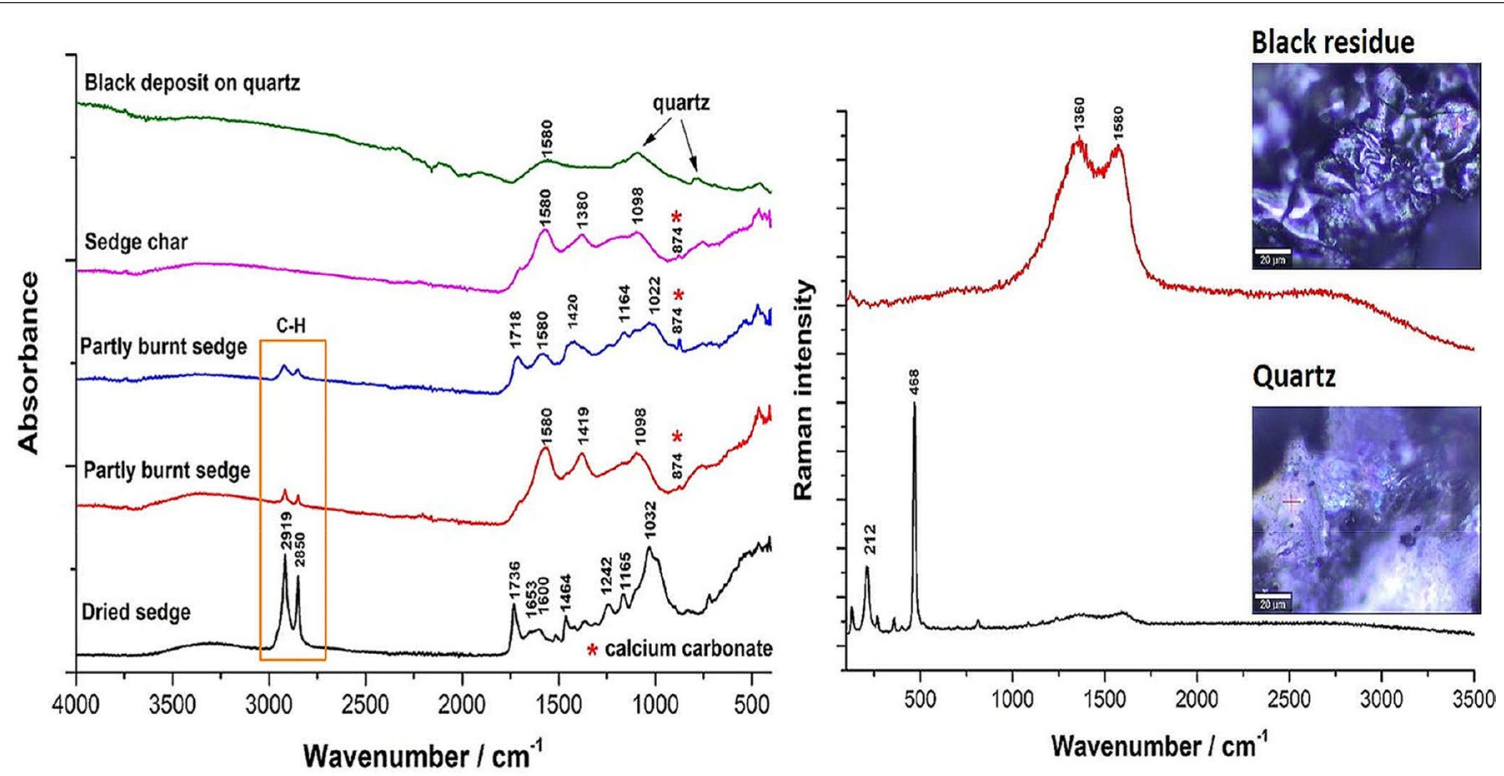

Fig. 5 FTIR spectra of dried, burnt and charred sedge compared to the FTIR spectrum of the black residue on the quartz (left). Images and Raman spectra of black residue and quartz adjacent to residue (right)

Bone mineral is a carbonated hydroxyl apatite $[(\mathrm{Ca}$, $\left.\mathrm{Na}, \mathrm{Mg})_{5}\left(\mathrm{HPO}_{4}, \mathrm{PO}_{4}, \mathrm{CO}_{3}\right)_{3}\left(\mathrm{OH}, \mathrm{CO}_{3}\right)\right]$ and contains organic phases such as collagen and other non-collagenous proteins such as osteocalcin. There are four lattice sites in the apatite structure, two occupied by $\mathrm{Ca}^{2-}$, the third by $\mathrm{PO}_{4}{ }^{3-}$ and the fourth by $\mathrm{OH}^{-1}$. Carbonate ions $\left(\mathrm{CO}_{3}{ }^{2-}\right)$ can replace both phosphate and hydroxide ions in the structure and therefore occupy two different 

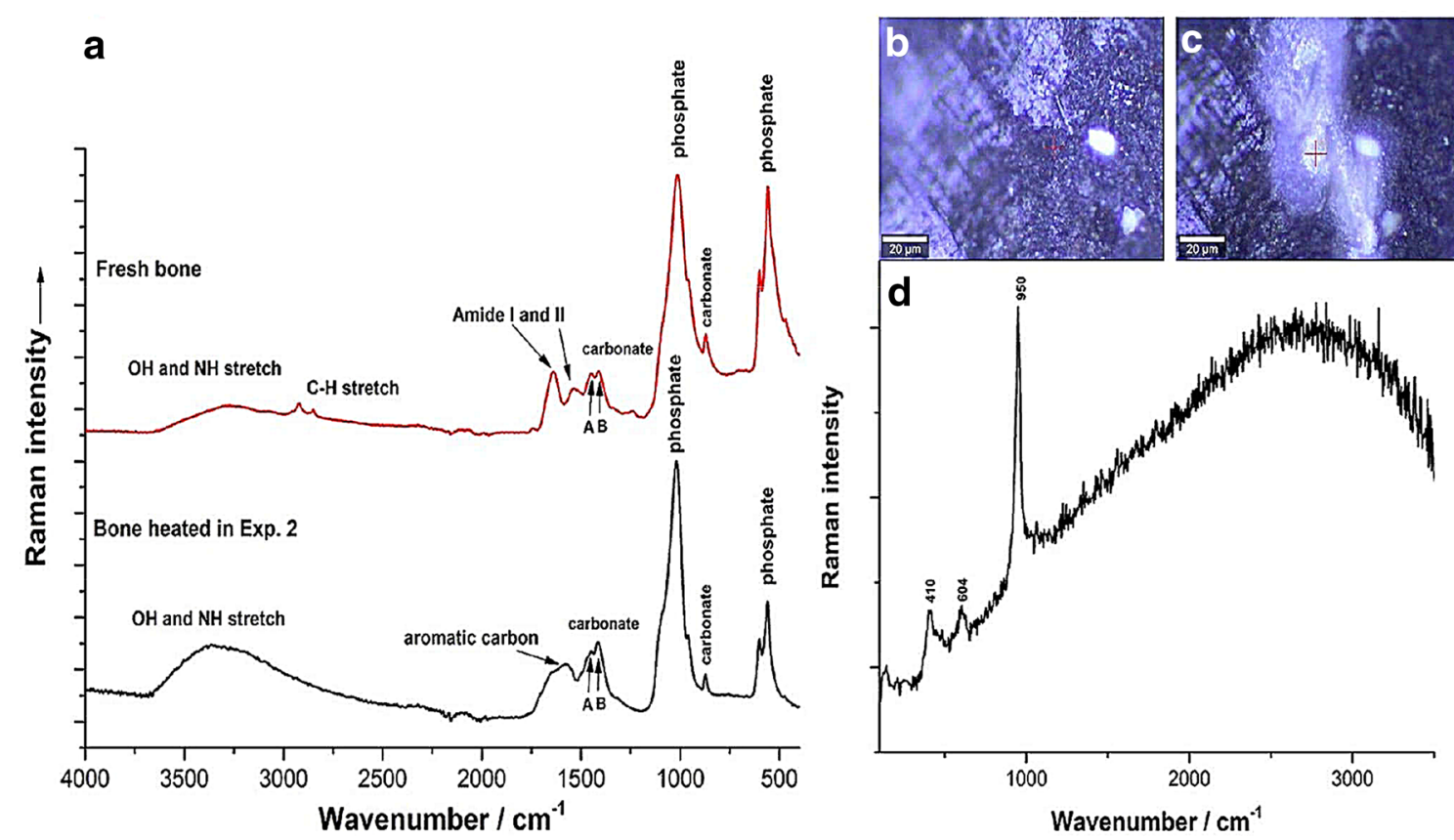

Fig. 6 FTIR and Raman spectra of bone. a The FTIR spectrum of a piece of bone heated in Experiment 2 compared to a spectrum of fresh pork bone. Image of bone $\mathbf{b}$ before and $\mathbf{c}$ after Raman analysis and $\mathbf{d}$ Raman spectrum of bone

crystallographic sites (A and B) giving rise to the split in the carbonate band $\left(\sim 1400 \mathrm{~cm}^{-1}\right)$ in the FTIR spectrum (Fig. 6a). Other bands originate from collagen (typical protein bands known as amide I and amide II) and bands from phosphate $\left(\mathrm{PO}_{4}{ }^{3-}\right)$ ions [29]. The changes that take place in bone heated in the presence of oxygen (e.g., directly in a fire) take place according to temperature. Between 25 and $100{ }^{\circ} \mathrm{C}$ poorly bounded water is lost and, then up to $250{ }^{\circ} \mathrm{C}$, structural water from proteins and mineral surface-bounded $\mathrm{H}_{2} \mathrm{O}$. The combustion of $50 \%$ of the organic phase, an increase in crystal size, and the formation of new mineral phases (e.g. $\mathrm{NaCaPO} 4, \mathrm{NaCl}$, and $\mathrm{KCl})$ take place between 300 and $500{ }^{\circ} \mathrm{C}$. Above $500{ }^{\circ} \mathrm{C}$, loss of the remaining organic components occurs and calcination is complete with the formation of crystalline $\beta$-tricalcium phosphate $\left(\mathrm{Ca}_{3}\left(\mathrm{PO}_{4}\right)_{2}\right)$.

The spectrum of the bone heated in Experiment 2 $\left(\sim 400{ }^{\circ} \mathrm{C}\right)$ on sedges underneath sand is similar to that of fresh bone, but the distinct peaks of amide 1 and II in the spectrum of fresh bone are replaced by a broad peak around $1580 \mathrm{~cm}^{-1}$ indicative of amorphous, mostly aromatic, structures. Furthermore, the full width at half maximum (FWHM) of the phosphate peaks has decreased, indicating partial recrystallisation of the phosphate carbonate structure. Figure $6 \mathrm{~b}-\mathrm{d}$ shows the Raman spectrum typical of bone apatite and the images recorded before and after the Raman analysis. Heat generated by the laser beam caused the remaining black organic residues to combust leaving the white inorganic apatite phase behind. The amorphous, mostly aromatic phases detected with Raman and FTIR spectroscopy originate from pyrolysis products of the organic fraction of bone. FTIR and Raman spectroscopy are not sensitive enough to detect micro amounts of organic material and only broad bands typical of amorphous carbon structures are observed.

\section{Gas chromatography-mass spectrometry (GC-MS)}

Detailed GC-MS results are presented in Additional file 2; a summary is given here. Microscopic traces of carbonised organic residues were detected on several pieces of bone and stone, but the GC-MS method is time consuming so bone and stone pieces displaying the largest residues were chemically tested. Overlays of black residue, burnt bone, fresh sedge and burnt sedge show that several of the derivatised compounds are common to the four samples and MS data support this (Additional file 2: Figure S1B and C). GC-MS measurements of the samples revealed that the black residue and burned bone share eight compounds with dried sedges and that several of the derivatised compounds are also common to all samples. These results suggest that the residues have derived from the heated sedges. The same compounds condensed on the uppermost lithic surfaces in small quantities that were not visible to the naked eye, but could be detected by GC-MS. 


\section{Discussion}

The experiments were designed to examine the effects of heating lithics buried in sand in contact with organic materials like sedges and bone. The aim was to observe whether organic residues form accidentally on such lithics buried $5 \mathrm{~cm}$ deep in sediment below small fires. The two field experiments were designed to replicate either post-depositional burning or deliberate underground heating in archaeological sites. Such burning can take place in sites of any age anywhere in the world, so our experimental results have broad implications even though the questions were designed with South African sites in mind. Field experiments produce far more variables than laboratory experiments where controls can be exercised, and we are aware that some of the complexity evident in our results has been caused by the unpredictability inherent in burning open-air wood fires. Nonetheless, unpredictable conditions also prevailed in the sites occupied by people in the past, so it is important to explore the potential variability. This preliminary study has raised questions that need answering with further experiments, and our results suggest that additional investigations would be worthwhile. The extent to which objects buried in sediment can be heated or burned by overlying fires will vary depending on firewood types used [1], site conditions, such as sediment texture and particle size, and the depth of burial [30-35]. Higher underground temperatures can be achieved in dry rather than moist sediments; heat load into wet soil is on average only $20 \%$ of that into dry soil [36]. In addition, sediment texture and particle size influence heat conductance and oxygen penetration below ground, respectively [30]. Hotter temperatures are reached in coarse sand than fine-grained, clayey loam [37] because coarse sand allows oxygen penetration below ground [30]. One of the questions arising here is whether the heated sediment itself contains products that can produce residues on lithics and bone? It is necessary to explore this possibility in future. We also need to conduct more experiments with fewer variables than those presently reported. Notwithstanding the gaps that these pilot experiments leave, our observations represent an important steppingstone towards understanding residue production on archaeologically recovered lithics and bone.

In Experiment 1 a layer of dry Cyperus textilis was buried under coarse/medium sand and in Experiment 2 the C. textilis culms were fresher (though reaped 3 weeks before the experiments). Both fires burned similar small masses ( $\pm 5 \mathrm{~kg}$ ) of Acacia karroo wood. Sediments $5 \mathrm{~cm}$ below the fire centre reached maximum temperatures of $438{ }^{\circ} \mathrm{C}$ in Experiment 1, and $426{ }^{\circ} \mathrm{C}$ in Experiment 2. Aldeias [38] predicted substantial underground thermal changes directly below the fire, not around its sides. This was confirmed; underground burning of organic material took place exclusively beneath the fire and not beyond its perimeter. Both the dry and the 'fresh' sedges were equally charred by the fires above them. As was the case in experiments by Stiner et al. [35], bone buried $5 \mathrm{~cm}$ underneath the fire burned black, but the colour of bone outside the fire perimeter was unchanged. So dramatic is the temperature difference underneath compared to on the edges of the fire, that bone pieces buried so that they straddled the fire and its perimeter were blackened on one half only. Organic petrology readings on some Sibudu bone pieces show that they burned at temperatures between 300 and $800{ }^{\circ} \mathrm{C}$ [39]. Such a range of temperatures implies, as we suspected, that different types of combustion occurred at this archaeological site and the position of a bone within or under a fire will influence its degree of burning.

Pyrolysis takes place in the absence of oxygen, resulting in a variety of products depending on the composition of the plant material and temperature. We have already mentioned that some oxygen can enter coarse-tomedium sand and therefore some combustion was possible in the sediment under our fires. Indeed, the sand used for our experiments was clearly porous enough to enable compounds to permeate through it after they vaporised from the heated organic materials. Upon cooling, the compounds condensed on objects in the surrounding sediments. This inference is consistent with the FTIR and Raman results that identified residues of carbonaceous material on the surfaces of lithics that were in direct contact with buried sedge that burned under the fire. Preliminary GC-MS measurements (Additional file 2) documented organic compounds in the black residue closely matching compounds identified in the sedge samples. It is not within the scope of this study to identify the compounds further, but it supports the idea that organic compounds are transferred from the sedge to the lithics. The largest amount of residue was on the surfaces that touched the sedges, but microscopic traces were also found on the uppermost surfaces. Laboratory burning experiments by other researchers have demonstrated that the organic constituents of fuel degrade when exposed to temperatures greater than $300{ }^{\circ} \mathrm{C}$ [40]. Braadbaart et al. [40] produced compounds between 300 and $400{ }^{\circ} \mathrm{C}$ that were mainly alkylated phenols and benzenes, but at higher temperatures these were replaced by condensed aromatic compounds. These field experiments may have produced similar results because the underground temperatures were over $400{ }^{\circ} \mathrm{C}$, but more detailed chemical analyses are required to be sure of this.

These experiments are not the only report of incidental black organic residues forming underground. Cnuts and colleagues [41] produced residue on a lithic through dry 
distillation when the lithic touched wood after both items were buried together under an experimental wood fire. A temperature of $340{ }^{\circ} \mathrm{C}$ and anaerobic conditions created suitable conditions for condensation of the terpenes [41].

\section{Conclusions}

The experiments reported here enable two significant conclusions. First, incidental organic residues can form on buried lithics and bone heated in the presence of plant material. The process can either be post-depositional or the unintended by-product of a deliberate task such as heat treatment of rocks. Secondly, black organic residues can form on lithics heated either underground or above ground in the presence of plant material. Pyrolysis can occur in either situation, but is more likely underground than in open fires where oxygen availability favours total combustion of organic material. A mixture of pyrolysis and combustion occurred under our experimental fires. As mentioned at the start of this paper, black organic residues can also be deposited on lithics from plant exudates created in aboveground embers [6]. We therefore conclude that black organic residues can be deposited on lithics heated together with plant material either above ground or underground. Carbonised organic residues on lithics should consequently not be considered reliable markers for aboveground heat treatment and this is a significant discovery for researchers studying such processes. The residues also cannot prove deliberate below ground heat treatment, but they leave open the possibility that this was sometimes the case when accidental burial was not implicated. The issue of whether the black residues are the product of incidental heating or deliberate heat treatment can sometimes be resolved by finding the chain of technical operations that materialised after the heating of rocks. The discovery of the carbonised organic residues on lithics from Klipdrift and Diepkloof provides a good example. After the heating process the residue-stained silcrete was knapped, leaving unstained scars that cross-cut the black residue $[3,6,7]$. It is thus clear that these residues were not post-depositional accidents and that they most likely formed while the rocks were being deliberately heat treated. Our production of similar residues on lithics buried $5 \mathrm{~cm}$ under a fire shows that the result might equally be obtained underground. It will be a challenge to find ways of distinguishing the heating methods based on residues. Additional experiments are needed because deliberate underground heat treatment implies analogical reasoning [4] and this attribute is therefore an important proxy for complex cognition of the kind present in modern humans. Such a proxy is relevant because the origins of heat treatment [2] are being pushed farther and farther into antiquity.

\section{Additional files}

Additional file 1: Table S1. Experiments 1 and 2: Items placed underground on sedges.

Additional file 2. Gas chromatology-mass spectrometry results

\section{Abbreviations}

GC-MS: gas chromatography-mass spectrometry; FTIR: Fourier transform infrared spectroscopy.

\section{Acknowledgements}

LP and SL acknowledge the use of University of Wollongong instruments and consumables, funded by the Australian Research Council through Australian Laureate Fellowship FL130100116 (awarded to Richard G. Roberts).

\section{Permission/permits}

No permission or permits were required for the experiments performed here. All materials were collected on LW's property.

\section{Authors' contributions}

LW designed the fire experiments, collected the materials, performed the fire experiments and wrote the paper. CS performed the fire experiments and contributed to the paper. SL performed the GC-MS and contributed to the paper. LP performed the Raman and FTIR and contributed to the paper. All authors read and approved the final manuscript.

\section{Funding}

LW's research was funded by a National Research Foundation (NRF), South Africa, African Origins Platform (AOP) Grant 98827. AOP grants specifically exclude funding of publication costs. The NRF is not responsible for and does not necessarily support the interpretations reached by the authors.

\section{Availability of data and materials}

The datasets used and/or analysed during the current study are available from the corresponding author on reasonable request. All the materials analysed for the study are curated at the Evolutionary Studies Institute, University of the Witwatersrand, Johannesburg.

\section{Competing interests}

The authors declare that they have no competing interests.

\section{Author details}

${ }^{1}$ Evolutionary Studies Institute, University of the Witwatersrand, PO Wits 2050, Johannesburg, South Africa. ${ }^{2}$ Centre for Archaeological Science, School of Earth, Atmospheric and Life Sciences, University of Wollongong, Wollongong, NSW 2522, Australia. ${ }^{3}$ School of Geography, Archaeology and Environmental Studies, University of the Witwatersrand, PO Wits 2050, Johannesburg, South Africa.

Received: 14 June 2019 Accepted: 2 August 2019

Published online: 08 August 2019

References

1. Bentsen SE. Controlling the heat: an experimental approach to Middle Stone Age pyrotechnology. S Afr Archaeol Bull. 2013;68:137-45.

2. Brown K, Marean CW, Herries AIR, Jacobs Z, Tribolo C, Braun D, et al. Fire as an engineering tool of early modern humans. Science. 2009;325:859-62.

3. Schmidt P, Porraz G, Slodczyk A, Bellot-Gurlet L, Archer W, Miller CE. Heat treatment in the South African Middle Stone Age: temperature induced transformations of silcrete and their technological implications. J Archaeol Sci. 2013;40:3519-31.

4. Wadley L, Prinsloo LC. Experimental heat treatment implies analogical reasoning in the Middle Stone Age. J Hum Evol. 2014;70:49-60.

5. Wadley L, de la Peña P, Prinsloo LC. Responses of South African agate and chalcedony when heated experimentally, and the broader implications 
for heated archaeological minerals. J Field Archaeol. 2017;42:364-77. https://doi.org/10.1080/00934690.2017.1337438.

6. Schmidt P, Porraz G, Bellot-Gurlet L, February E, Ligouis B, Paris C, et al. A previously undescribed organic residue sheds light on heat treatment in the Middle Stone Age. J Hum Evol. 2015;85:22-34. https://doi, org/10.1016/j.jhevol.2015.05.001.

7. Delagnes A, Schmidt P, Douze K, Wurz S, Bellot-Gurlet L, Conard NJ, et al. Early evidence for the extensive heat treatment of silcrete in the Howiesons Poort at Klipdrift Shelter (Layer PBD, 65 ka), South Africa. PLoS ONE. 2016;11(10):e0163874. https://doi.org/10.1371/journal.pone.0163874.

8. Mallol C, Hernández CM, Cabanes D, Sistiaga A, Machado J, Rodríguez T, et al. The black layer of Middle Palaeolithic combustion structures. Interpretation and archaeostratigraphic implications. J Archaeol Sci. 2013:40:2515-37.

9. Wadley L, Lombard M. Small things in perspective: the contribution of our blind tests to micro-residue studies on archaeological stone tools. J Archaeol Sci. 2007;34:1001-10.

10. Goldberg P, Miller CE, Schiegl S, Ligouis B, Berna F, Conard NJ, et al. Bedding, hearths, and site maintenance in the Middle Stone Age of Sibudu Cave, KwaZulu-Natal, South Africa. Archaeol Anthropol Sci. 2009;1 (2):95-122.

11. Sievers C. Experimental sedge bedding and the taphonomic implications for Sibudu Cave, KwaZulu-Natal. S Afr Archaeol Bull. 2013;68:200-10.

12. Wadley L, Sievers C, Bamford M, Goldberg P, Berna F, Miller CE. Middle Stone Age bedding construction and settlement patterns at Sibudu, South Africa. Science. 2011;334:1388-91.

13. Lennox S, Bamford M. Identifying Asteraceae, particularly Tarchonanthus parvicapitulatus, in archaeological charcoal from the Middle Stone Age. Quat Int. 2017;457:155-71.

14. Bordes L, Prinsloo LC, Fullagar R, Sutikna T, Hayes E, Jatmiko, et al. Viability of Raman microscopy to identify micro-residues related to tool-use and modern contaminants on prehistoric stone artefacts. J Raman Spectrosc. 2017:48:1212-21. https://doi.org/10.1002/jrs.5202.

15. Prinsloo LC, Bordes L. Raman microscopy as a primary technique for identifying microresidues related to tool-use on prehistoric stone artefacts. In: Vandenabeele P, Edwards H, editors. Raman spectroscopy in archaeology and art history, vol. 2. Cambridge: The Royal Society of Chemistry; 2019. p. 81-96.

16. Monnier GF, Frahm E, Luo B, Missal K. Developing FTIR microspectroscopy for analysis of plant residues on stone tools. J Archaeol Sci. 2017;78:158-78.

17. Monnier G, Frahm E, Luo B, Missal K. Developing FTIR microspectroscopy for the analysis of animal-tissue residues on stone tools. J Archaeol Method Theory. 2018. https://doi.org/10.1007/s10816-017-9325-3.

18. Prinsloo LC, Wadley L, Lombard M. Infrared reflectance spectroscopy as an analytical technique for the study of residues on stone tools: potential and challenges. J Archaeol Sci. 2014;41:732-9.

19. Charrié-Duhaut A, Porraz G, Cartwright CR, Igreja M, Connan J, Poggenpoel C, et al. First molecular identification of a hafting adhesive in the late Howiesons Poort at Diepkloof Rock Shelter (Western Cape, South Africa). J Archaeol Sci. 2013;40:3506-18.

20. d'Errico F, Backwell LR, Villa P, Degano I, Lucejko J, Bamford M, et al. Early evidence of San material culture represented by organic artifacts from Border Cave, South Africa. Proc Nat Acad Sci USA. 2012;109:13214-9.

21. Luong S, Hayes E, Flannery E, Sutikna T, Tocheri MW, Saptomo EW, et al. Development and application of a comprehensive analytical workflow for the quantification of non-volatile low molecular weight lipids on archaeological stone tools. Anal Methods. 2017;9:4349-62.

22. Luong S, Tocheri MW, Sutikna T, Saptomo EW, Jatmiko, Roberts RG. Incorporating terpenes, monoterpenoids and alkanes into multiresidue organic biomarker analysis of archaeological stone artefacts from Liang Bua (Flores, Indonesia). J Archaeol Sci Rep. 2018:19:189-99.
23. Mathe C, Archier P, Nehme L, Vieillescazes C. The study of Nabataean organic residues from Madâin Sâlih, ancient Hegra, by gas chromatography-mass spectrometry. Archaeometry. 2008. https://doi.org/10.111 1/j.1475-4754.2008.00417.

24. Regert M. Investigating the history of prehistoric glues by gas chromatography-mass spectrometry. J Sep Sci. 2004;27:244-54. https://doi. org/10.1002/jssc.200301608.

25. Wentworth CK. A scale of grade and class terms for clastic sediments. J Geol. 1922;30:377-92.

26. Lennox S, Bamford M, Wadley L. Middle Stone Age wood use 58000 years ago in KwaZulu-Natal: charcoal analysis from two Sibudu occupation layers. South Afr Humanit. 2017;30:247-86.

27. Balogun AO, Sotoudehniakaranib F, McDonald AG. Thermo-kinetic, spectroscopic study of brewer's spent grains and characterisation of their pyrolysis products. J Anal Appl Pyrolysis. 2017;127:8-16.

28. El-Hendawy AA. Variation in the FTIR spectra of a biomass under impregnation, carbonization and oxidation conditions. J Anal Appl Pyrolysis. 2006;75:159-66.

29. Mamede AP, Gonçalves D, Marques MPM, Batista de Carvalho LAE. Burned bones tell their own stories: a review of methodological approaches to assess heat-induced diagenesis. Appl Spectrosc Rev. 2018;53:603-35.

30. Aldeias V, Dibble HL, Sandgathe D, Goldberg P, McPherron SJP. How heat alters underlying deposits and implications for archaeological fire features: a controlled experiment. J Archaeol Sci. 2016;67:64-79.

31. Canti MG, Linford NT. The effects of fire on archaeological soils and sediments: temperature and colour relationships. Proc Prehist Soc. 2000;66:385-95.

32. DeBano LF. The effect of fire on soil properties. In: Paper presented at the symposium on management and productivity of Western-Montane Forest Soils, Boise, ID, April 10-12; 1990.

33. Miller $C E$, Sievers $C$. An experimental micromorphological investigation of bedding construction in the Middle Stone Age of Sibudu, South Africa. J Archaeol Sci. 2012;39:3039-51. https://doi.org/10.1016/j.jas.2012.02.007.

34. Sievers C, Wadley L. Going underground: experimental carbonization of fruiting structures under hearths. J Archaeol Sci. 2008;35:2909-17.

35. Stiner MC, Kuhn SL, Weiner S, Bar-Yosef O. Differential burning, recrystallisation, and fragmentation of archaeological bone. J Archaeol Sci. 1995:22:223-7.

36. Frandsen WH, Ryan KC. Soil moisture reduces below ground heat flux and soil temperatures under a burning fuel pile. Can J For Res. 1986;16:244-8.

37. March RJ, Lucquin A, Joly D, Ferreri JC, Muhieddine M. Processes of formation and alteration of archaeological fire structures: complexity viewed in the light of experimental approaches. J Archaeol Method Theory. 2014;21:1-45.

38. Aldeias V. Experimental approaches to archaeological fire features and their behavioral relevance. Curr Anthropol. 2017;58(Supplement 16):191-205

39. Clark JL, Ligouis B. Burned bone in the Howieson's Poort and post-Howieson's Poort Middle Stone Age deposits at Sibudu (South Africa): behavioral and taphonomic implications. J Archaeol Sci. 2010;37:2650-61.

40. Braadbaart F, Poole I, Huisman HDJ, van Os B. Fuel, fire and heat: an experimental approach to highlight the potential of studying ash and char remains from archaeological contexts. J Archaeol Sci. 2012;39:836-47.

41. Cnuts $D$, Tomasso $S$, Rots V. The role of fire in the life of an adhesive. J Archaeol Method Theory. 2017;25:839-62. https://doi.org/10.1007/s1081 6-017-9361-z

\section{Publisher's Note}

Springer Nature remains neutral with regard to jurisdictional claims in published maps and institutional affiliations. 